\title{
Basophil degranulation induced by cigarette smoking in man
}

\author{
S WALTER, A WALTER
} From the Departments of Physiology and Pathology, Christian Medical College and Hospital, Vellore,
South India

ABSTRACT There is some evidence that histamine could be a mediator of the immediate bronchoconstriction that follows cigarette smoking. Since the chief reservoir of histamine in normal human blood is the basophil, we studied the acute effects of cigarette smoking on these cells. Capillary blood samples were obtained from 27 healthy young male smokers, before and 10 minutes after smoking. Basophils were collected and concentrated from these samples by a millipore membrane filter technique, stained with toluidine blue, and classified according to the staining characteristics and location of their cytoplasmic granules. This classification differentiated the "intact" from the "degranulated" basophils. A significant increase in degranulated cells and decrease in intact cells ( $p<0.001$ ) was observed after smoking. Since histamine is present in the basophil granules, these findings suggest that cigarette smoking causes histamine release.

One of the immediate effects of cigarette smoking has been shown to be bronchoconstriction. ${ }^{1-3}$ The prompt and reversible nature of this effect' suggests that it is caused by smooth muscle contraction. The exact mechanism by which this effect is mediated is not, however, known. Direct stimulation of the mechanoreceptors in the airways by the particulate matter in the smoke ${ }^{4}$ or release of histamine ${ }^{5}$ or both, has been suggested. The chief reservoir of histamine in the blood is basophilic leucocytes. ${ }^{6}$ These cells have been shown to release histamine on degranulation. ${ }^{7}$ Recently it has been observed that there is a significant fall in the total basophil concentration as an acute effect of cigarette smoking. ${ }^{89}$ A decrease in the number of circulating basophils is generally considered to be due to degranulation and consequent loss of identity of the cells in a count. Possibly, however, it could also be due to migration of basophils into the airway lumen, as part of a leucocyte recruitment response ${ }^{10}$ to smoking. The present study was undertaken to determine whether the basopenia observed immediately after cigarette smoking was due to degranulation.

\section{Methods}

The subjects were 27 healthy young male smokers. Their physical characteristics and smoking habits are

Address for reprint requests: Professor S Walter, Christian Medical College, Vellore 632002, South India. shown in table 1. They were asked to abstain from smoking for at least 12 hours before the test, so that any immediate effects due to previous smoking would be minimised. Tests were all done between 8.00 and $11.00 \mathrm{am}$. Two capillary blood samples of $0.05 \mathrm{ml}$ were collected from each subject before smoking, and 10 minutes after the completion of smoking one to two cigarettes.

Collection and concentration of basophils were done by a modification of the method of Shelley and Juhlin." The blood samples were rapidly fixed in a chilled non-aqueous mixture containing $60 \%$ of methyl alcohol, $20 \%$ of glacial acetic acid, and $20 \%$ of chloroform, stored overnight at $0-4^{\circ} \mathrm{C}$, then lightly centrifuged, filtered with a solvent-resistant millipore membrane filter of $5 \cdot 0 \mu \mathrm{m}$ size (Metricel GA-1), and stained with alcoholic toluidine blue. The stained membrane filter was dehydrated, cleared, and mounted on a glass slide and examined under oil with a total magnification of $\times 1000$.

All the white cells other than basophils were seen as

Table 1 Physical characteristics and smoking habits of the subjects $(n=27)$

\begin{tabular}{lrr}
\hline & Mean & $\pm S D$ \\
\hline Age (y) & 21.3 & 2.56 \\
Height (cm) & 173.5 & 5.60 \\
Weight (kg) & 60.9 & 6.41 \\
Duration of smoking (y) & 4.3 & 2.73 \\
No of cigarettes smoked each day & 7.3 & 7.73 \\
\hline
\end{tabular}


pale blue, ghost-like cells. In contrast, the basophils appeared well defined and distinct with specific reddish-purple, metachromatic granules in the cytoplasm. The entire membrane filter was scanned systematically and all the basophils were counted and categorised. Categorisation was done on the basis of the staining characteristics and location of the cytoplasmic granules; we used a simplified version of the classification of Shelley and Juhlin, ${ }^{11}$ which divides basophils into three major groups- A, B, and C. A cells have very deeply staining granules, which are fused or aggregated with each other and form clumps; these cells are rare. B cells are the most numerous; they have many deeply staining granules which are distinct and separate from each other. $C$ cells are less numerous than $B$ and have small, faintly staining granules. These authors further subdivided each group into six types, according to the number and location of the granules. In our study we were unable to find A cells in any of the subjects. Moreover, we found that classification of each group into the six types was prone to subjective errors. We therefore classified the cells into: B cells-cells with discrete, deeply staining granules in the cytoplasm (fig 1); C cells—cells with discrete but poorly staining granules in the cytoplasm (fig 2); D cells-cells from which the granules had been released, giving rise to a "spray" effect around the cells (fig 3 ).

For each subject a total of four slides was studied; two were from the blood samples taken before they smoked, and two from those taken after smoking. Since on an average each slide had about 50 basophils, about 100 cells were studied before and 100 after smoking. Grouping of the basophils in all the slides was performed by a single observer. It was done blind, all the specimens being coded by a second observer.

\section{Results}

The data are expressed in terms of basophil "differential counts" (table 2). Before smoking the basophils consisted of $70.2 \%$ B cells, $22.5 \% \mathrm{C}$ cells, and $7.3 \% \mathrm{D}$ cells; whereas after smoking they consisted of $57.8 \%$ B cells, $24 \cdot 1 \% \mathrm{C}$ cells, and $18 \cdot 1 \% \mathrm{D}$ cells. The decrease in the $B$ cells and the increase in the D cells were significant $(\mathrm{p}<0.001)$ by the paired $t$ test.



Fig 2

Fig 1 B cell with deeply staining granules in the cytoplasm (alcoholic toluidine blue, $\times 1600$ ).

Fig 2 cell with poorly staining granules in the cytoplasm (alcoholic toluidine blue, $\times 1600$ ).

Fig $3 D$ cell with released granules outside the cell (alcoholic toluidine blue, $\times 1600$ ). 
Table 2 Changes in basophils following cigarette smoking $(n=27)$

\begin{tabular}{|c|c|c|c|c|c|c|}
\hline \multirow[t]{2}{*}{ Basophil type* } & \multicolumn{2}{|l|}{ Before } & \multicolumn{2}{|l|}{ After } & \multirow{2}{*}{$\begin{array}{l}\text { SEM of } \\
\text { difference }\end{array}$} & \multirow[t]{2}{*}{$p^{\dagger}$} \\
\hline & Mean & $\pm S D$ & Mean & $\pm S D$ & & \\
\hline $\begin{array}{l}\mathrm{B} \text { cells }(\%) \\
\mathrm{C} \text { cells }(\%) \\
\mathrm{D} \text { cells }(\%)\end{array}$ & $\begin{array}{r}70 \cdot 2 \\
22 \cdot 5 \\
7 \cdot 3\end{array}$ & $\begin{array}{l}6.41 \\
4.98 \\
3.07\end{array}$ & $\begin{array}{l}57 \cdot 8 \\
24 \cdot 1 \\
18 \cdot 1\end{array}$ & $\begin{array}{l}7 \cdot 00 \\
3 \cdot 73 \\
5 \cdot 45\end{array}$ & $\begin{array}{l}1 \cdot 189 \\
1 \cdot 051 \\
0 \cdot 677\end{array}$ & $\begin{array}{l}<0-001 \\
\text { NS } \\
<0-001\end{array}$ \\
\hline
\end{tabular}

*Classification of cells modified from Shelley and Juhlin" - -see under "Methods."

$\div$ Paired $t$ test.

\section{Discussion}

Although the function of the basophil is not fully understood, there is growing knowledge of the mechanism of degranulation of these cells and the conditions in which this occurs. ${ }^{12}$ Dvorak et al have studied degranulation in human basophils in detail. ${ }^{13}$ It has been observed that loss of granule material may occur in one of two ways: individual granule exteriorisation by fusion of granule membrane with cell membrane, or vesicular transport of granular material to the exterior, the latter occurring in circumstances when there is slow release of granule material. It is suggested that under physiological conditions, or in the process of collecting blood for isolation of these cells, there is probably a slow release of granular material. Thus in blood samples collected for study of basophils there might be intact cells with their full complement of granules which stain deeply, cells from which there has been some slow loss of granular material and which therefore stain faintly, and cells from which all the granules or granular material have been released. In the present study, in the blood samples obtained before smoking $70.2 \%$ of the basophils had their full complement of granules (B cells). A further $22.5 \%$ were probably cells undergoing slow loss of granular material (C cells), and the remaining $7 \cdot 3 \%$ were cells from which granules seemed to have been released or to be in the process of being released en masse and could be seen surrounding the cell (D cells). From the staining characteristics of the granules released from the cells it could be seen that these $D$ cells included degranulated cells of both B and C types. After smoking there was a shift of this differential count to the right, with a decrease in the $B$ cells and an increase in the D cells, indicating that degranulation of the basophils had occurred. The relative lack of change in the $\mathrm{C}$ cells may be explained if it is assumed that, while some $C$ cells were converted to $D$ cells, some of the B cells were converted either to D cells or to C cells, the net number of $C$ cells remaining about the same.

Of the many chemicals known to be present in human basophils, one of the most important is histamine. Since histamine is localised in the granules, degranulation of these cells is accompanied by release of histamine. ${ }^{7}$ This study therefore provides evidence for histamine release after cigarette smoking. The observations reported here confirm previous reports from our laboratory and elsewhere. In dogs it has been shown that the bronchoconstrictor effect of cigarette smoke is abolished after administration of inhibitors of histamine synthesis ${ }^{5}$; and ventilation with cigarette smoke has been shown to cause histamine release from perfused lung lobes. ${ }^{14}$ In normal young men smoking induces a significant fall in the blood basophil count. ${ }^{9}$ In isolated monkey lungs artificially ventilated with cigarette smoke a significant decrease in the total mast cell counts has been found. ${ }^{15}$ The mast cell, like its congener the basophil, contains histamine in association with its granules and releases this chemical on degranulation. ${ }^{16} \mathrm{~A}$ completely degranulated mast cell therefore cannot be identified during a count and thus the count decreases. There is further indirect evidence to support the view that histamine release occurs after smoking. Cigarette smokers have been observed to have higher histamine concentrations in blood than non-smokers ${ }^{17}$; furthermore, total blood basophil counts are higher in smokers after a brief period of abstinence from smoking than in non-smokers. ${ }^{18}$

The actions of histamine on the lung mechanics of man and other mammals have been studied extensively. In man it causes narrowing of small airways, as indicated by decreased maximal expiratory flows at low lung volumes, increased ratio of elastic recoil to maximal expiratory flow, and decreased partial expiratory flow rates. It is known to cause bronchoconstriction in man and animals and has been shown to cause a reduction in the collateral ventilation of the lung in dogs. ${ }^{19}$ The similarity between many of the pulmonary effects of histamine and those of cigarette smoke and the fact that histamine is released by cigarette smoking suggest that histamine might be an important mediator of the immediate effects of smoking.

Moreover, histamine is known to play a key role in inflammatory reactions, causing increased vascular permeability, oedema, and increased glandular secretions. ${ }^{20} \mathrm{~A}$ slow histamine release has also been implicated in some chronic lung disorders. Kawanami 
and associates ${ }^{21}$ found hyperplasia and evidence of a chronic process of partial degranulation of lung mast cells in patients with fibrotic lung disorders, and suggested that a chronic slow release of histamine and other mediators may contribute to the changes observed. A similar mechanism might possibly contribute to the development of chronic inflammatory and obstructive changes seen in the airways of smokers with chronic obstructive lung disease.

Susceptibility to the ill effects of smoking is known to vary widely between individuals, and not all who smoke develop chronic obstructive lung disease. ${ }^{22}$ This variation probably reflects an inherent sensitivity to tobacco smoke, in which immunological mechanisms may or may not play a part. ${ }^{23} 24$ The fact that the reactivity of the airways may be an important determinant in the development of chronic obstructive lung disease may be relevant here. ${ }^{25}$ In individuals with hyperreactive airways the threshold for histamine-induced bronchoconstriction is lower than normal. ${ }^{26}$ Such subjects would therefore be expected to have greater ill effects in the lung from smoking, leading to a more rapid development of the disease.

This study was supported by a grant from the Indian Council of Medical Research, New Delhi. We wish to thank the subjects who volunteered for the study and Mrs B Jyothi for technical assistance. The assistance of Mr M S Irudayaraj in the preparation of the manuscript is gratefully acknowledged.

\section{References}

${ }^{1}$ Nadel JA, Comroe JH jun. Acute effects of inhalation of cigarette smoke on airway conductance.J Appl Physiol 1961;16:713-6.

${ }^{2}$ Sterling GM. Mechanism of bronchoconstriction caused by cigarette smoking. $\mathrm{Br}$ Med J 1967;iii:275-7.

${ }^{3}$ Walter S. The immediate airway response to cigarette smoking. Indian J Med Res 1979;70:819-24.

4 Sellick H, Widdicombe JG. Stimulation of lung irritant receptors by cigarette smoke, carbon dust and histamine aerosol. J Appl Physiol 1971;31:15-9.

5 Palacek F, Oskoui M, Aviado DM. Pulmonary effects of tobacco and related substances. III-Inhibition of synthesis of histamine in various species. Arch Environ Health 1967;15:204-13.

${ }^{6}$ Graham HT, Lowry OH, Wheelright F, Lenz MA, Parish HH. Distribution of histamine among leukocytes and platelets. Blood 1955;10:467-81.

7 Sampson D, Archer GT. Release of histamine from basophils. Blood 1967;29:722-36.

${ }^{8}$ Frick G. Quoted by Winkel P, Statland BE. The acute effect of cigarette smoking on the concentrations of blood leukocyte types in healthy young women. Am J Clin Pathol 1981;75:781-5.

${ }^{9}$ Walter S, Nancy NR. Basopenia following cigarette smoking. Indian J Med Res 1980;72:422-5.

${ }^{10}$ Kilburn KH, McKenzie W. Leukocyte recruitment to airways by cigarette smoke and particle phase in contrast to cytotoxicity of vapor. Science 1975;189: 634-7.

1 Shelley WB, Juhlin L. Functional cytology of the human basophil in allergic and physiologic reactions: technic and atlas. Blood 1962;19:208-16.

12 Dvorak AM, Dvorak HF. The basophil: its morphology, biochemistry, motility, release reactions, recovery and role in the inflammatory responses of IgE-mediated and cell-mediated origin. Arch Pathol Lab Med 1979; 103:551-7.

${ }^{13}$ Dvorak AM, Newball HH, Dvorak HF, Lichtenstein LM. Antigen induced IgE-mediated degranulation of human basophils. Lab Invest 1980;43:126-39.

${ }^{14}$ Aviado DM, Samanek M, Folle LE. Cardiopulmonary effects of tobacco and related substances. Arch Environ Health 1966;12:705-11.

15 Walter A, Walter S. Mast cell population density of isolated monkey lungs before and after exposure to cigarette smoke. Thorax 1982;37:699-702.

${ }^{16}$ Uvnäs B. The mechanism of histamine liberation. $J$ Pharm Pharmacol 1958;10:1-13.

${ }^{17}$ Samanek M, Aviado DM. Bronchopulmonary effects of tobacco and related substances. II-Bronchial arterial injections of nicotine and histamine. Arch Environ Health 1965;11:152-9.

${ }^{18}$ Walter S. Blood basophil counts in smokers and nonsmokers. Indian J Med Res (in press).

19 Bouhuys A. The physiology of breathing. New York: Grune and Stratton, 1977.

${ }^{20}$ Brocklehurst WE. The pharmacology of asthma and possible therapeutic developments. In: Porter R, Birch $\mathrm{J}$, eds. Ciba Foundation symposium on identification of asthma. London: Churchill Livingstone, 1971:132-42.

${ }^{21}$ Kawanami O, Ferrans VJ, Fulmer JD, Crystal RG. Ultrastructure of pulmonary mast cells in patients with fibrotic lung disorders. Lab Invest 1979;40:717-34.

${ }^{22}$ Cochrane GM, Benatar SR, Davis J, Collins JV, Clark TJH. Correlation between tests of small airway function. Thorax 1974;29:172-8.

${ }^{23}$ Lehrer SB, Wilson MR, Karr RM, Salvaggio JE. IgE antibody response of smokers, non-smokers and "smoke sensitive" persons to tobacco leaf and smoke antigens. Am Rev Respir Dis 1980;121:168-70.

${ }^{24}$ Sudan BJL, Sterboul J. Nicotine: an hapten. $B r J$ Dermatol 1981;104:349.

${ }^{25}$ Britt JE, Cohen B, Menkes H, Bleecker E, Permutt S, Rosenthal R, Norman P. Airways reactivity and functional deterioration in relatives of COPD patients. Chest 1980;77,suppl:260.

${ }^{26}$ Boushey HA, Holtzman MJ, Sheller JR, Nadel JA. Bronchial hyperreactivity. Am Rev Respir Dis 1980; 121:389-413. 